\title{
RELATIONSHIP BETWEEN QUALITY AND PERFORMANCE: TOURISM COMPANIES IN THE CZECH REPUBLIC
}

\section{Milan Sedláček, Petr Suchánek, Jiř̌ Špalek, Petra Štamfestová}

Faculty of Economics and Administration, Masaryk University, Lipová 41a, 60200 Brno, Czech Republic, e-mail: milan.sedlacek@mail.muni.cz, suchycz@yahoo.com, spalek@econ.muni.cz, stamfestova.petra@mail.muni.cz

\begin{abstract}
This article analyzes perception of quality as a factor of performance of companies operating in the tourism industry. The introduction defines business performance and quality with a focus on tourism companies. A synthesis of findings from empirical studies conducted abroad follows, and is focused on the determinants of performance of a company (success), including the quality management which emerged as one of the important factors, and so these findings justify the importance of quality management in business practice. The aim of this article is to find the perception of quality and emphasis on the quality management of tourism companies in the Czech Republic. To identify the specific characteristics of quality perception and management in this sector, comparative analysis of questionnaire results, and results of a financial analysis of companies from various sectors of the Czech economy, with emphasis on tourism, has been used. It has been proved that enterprises in the sectors surveyed perceive quality as the key factor in business performance; it was also empirically shown that companies with higher levels of service quality reach better values of financial indicators. Also it was found that although tourism companies perceive the service quality of as one of the key success factors, the level of its actual implementing is low. This is related to the fact that relatively good financial results can be achieved in this industry without adjustment of the maximum customer service. This fact is also confirmed by the findings that show that in comparison to companies in other sectors, tourism companies still perceive relationship between quality production and business performance as substandard.
\end{abstract}

Key words: competitiveness, quality, financial analysis

JEL Classification: L83,L15, L25, M21

DOI: $10.2478 / \mathrm{v} 10135-011-0013-\mathrm{z}$ 


\title{
RELATIONSHIP BETWEEN QUALITY AND PERFORMANCE: TOURISM COMPANIES IN THE CZECH REPUBLIC
}

\author{
Milan Sedláček, Petr Suchánek, Jiří Špalek, Petra Štamfestová
}

\section{Introduction}

The paper focuses on a problem that is usually not solved in literature. Of course, there is a group of studies which deals with quality, service quality or performance, but authors did not find any specialized studies that look into the relationship between service quality and performance, moreover in conditions of the Czech Republic. For us, the most important thing is to fill this white place of science. Because of $63.6 \%$ enterprises in the Czech Republic pursue in the service sector (Czech Statistical Office, 2010), it is fundamental to asnwer the question of their quality, and especially the influence of their quality to their performance, thanks to permanently increasing and changing competitive environment.

Drawing on previous researches, it may be stated that the majority of companies in the Czech Republic see the quality of their product or service standing qualitatively above the average. Simultaneously, these companies recognize that good quality of their products has a positive influence on their corporate performance and competitiveness (for further details see Blažek et al., 2009). In this light, the article focuses on an analysis of specific traits of quality perception and management in the tourism sector.

In the first part of the article, basic terms which are used later in the text are defined. The second chapter focuses on the theory concerning interaction between quality and company performance, available in contemporary Czech and foreign literature. After creating a sufficient theoretical base an explanation of methodology follows, which was used in the primary research of quality perception in tourism companies and of the significance that the companies ascribe to the connection between the quality of a product or service and the performance and competitiveness of the company itself. Results of this research are presented in the fourth part. The final part of the article focuses on a comparison of ideas obtained from local and global literature with the results of our research, on reaching conclusions from those results, and on introduction of further possible directions of research into these issues.

The aim of this study is to analyze and compare quality of tourism companies and companies operating in other industries in the Czech Republic. To help reach the main objective, we set these partial aims:

- to analyze the different understandings of quality, performance, competitiveness, success and customer satisfaction, including their interrelations;

- to analyze ways of implementing quality management;

- to analyze the influence of quality on performance and competitiveness of a company. 


\section{Theoretical delineation of basic terms and relations between them}

Performance of a company can be measured in many different ways. The usually adopted approach evaluates the performance by financial ratios such as return on investment (Duchesneau and Gartner 1990; Smith, Bracker and Miner 1987), return on sales (Kean et al. 1998), or return on equity (Richard 2000; Barney 1997). In case of a new firm without any profit history, actual amount of revenues or more commonly number of employees (Orser, Hogarth, Riding 2000, Mohr, Spekman 1994, Robinson, Sexton 1994, Srinavasan, Woo, Cooper 1994, Loscocco, Leicht 1993, Davidson 1991, O'Farrel 1986) could be used. Moreover, there are other opportunities how to evaluate firm performance: dynamic variables such as improvement in ROI in time (Miller, Wilson, Adams 1988), other financial ratios like revenues/income per worker (Johannison 1993, Bade 1986), or income of the entrepreneur (Denison and Alexander 1986, Dollinger 1985, Sexton, Robinson 1989, Smith, Bracker, Miner 1987), i.e. a variable often used in the tourism industry in particular.

It is commonly recommended to use a combination of the measures mentioned above because only this complex evaluation could bring objective results of firm performance measuring (Westhad, Wright, Ucbaseran 2001, Kalleberg, Leicht 1991, Birley, Westhead 1990). For example, Lerner and Haber (2001) focused in their research on performance factors of small tourism ventures, and they used three variables for evaluation of the firm performance - revenues, profitability, and income. Haber and Reichel (2005) went in their research beyond these three measures and created "performance measures matrix of small ventures in tourism industry" - see the table below.

Table 1: performance measures matrix of small ventures in tourism industry

\begin{tabular}{|c|c|c|}
\hline Long-term & $\begin{array}{ll}\text { - } & \text { growth in revenues } \\
\text { - } & \text { growth in number of } \\
\text { employees }\end{array}$ & $\begin{array}{l}\text { - development and growth } \\
\text { - } \quad \text { tourism and business strength } \\
\text { - } \\
\text { success in generating profit in } \\
\text { times geopolitical crisis }\end{array}$ \\
\hline \multirow[t]{2}{*}{ Short-term } & $\begin{array}{ll}\text { - } & \text { revenues } \\
\text { - } & \text { number of employees } \\
\text { - } & \text { revenues per employee }\end{array}$ & $\begin{array}{l}\text { - occupancy and customer } \\
\text { satisfaction } \\
\text { - } \quad \text { profitability compared to } \\
\text { competitors }\end{array}$ \\
\hline & Obiect & Subiective \\
\hline
\end{tabular}

Source: Haber, Reichel (2005) 
The last example of a group of firm performance measures could include four indicators used by Morrison and Teixera (2004). In their research concerned with small business performance focused particularly on tourism sector, firm performance was measured by bedroom occupancy rate, annual revenue, break-even point, and guest satisfaction. It seems that they combined objective and subjective measures as well. However, they collected data only from questionnaires, and from this point of view all variables are subjective (from the owner-manager view).

Considering the fact that a company's output is value, it is clear that efficiency is, or rather can be, the criterion of performance. The absolute value of this indicator is commonly related to a chosen basis, which comprises of inputs (e.g. in the form of expenses or capital, resources etc.). From this point of view, the terms efficiency, performance and success rate (in its narrow meaning) can be considered synonymous.

The term competitiveness can also be defined in this theoretical framework. It can be described as a characteristic that allows a company to succeed in competition with other companies. It is clear that only those that can suitably apply the particular competitive advantage and thus gain supremacy over their rivals can succeed in the market.

Considering the fact that competitiveness of a company is connected to its vision of the future, and this vision influences the business strategy (which the owner supplies), there is the possibility of measuring competitiveness of a company through value, or its magnitude. From this point of view, performance is a condition for competitiveness and it should be true that if a company is competitive, its performance is also high and creates value - thus, if competitiveness grows, the value of the company grows, too.

As value creation is connected with the output of a company, it is clear that performance and competitiveness also has to be connected with this output. The output is determined by the product, particularly by its quality. The term product quality then includes not only advanced technology (in the sense of production technology or the form and level of service provision, and also technical or product sophistication), but mainly the ability to satisfy the demands of customers - the more the product is in line with a customer's requirements, the higher is its quality.

While defining the term quality, it is necessary to note that one correct definition of what exactly quality is does not exist. For example, Garvin (Garvin, 1987, Garvin, 1984) defines five basic building blocks of quality together with its eight dimensions, the fulfilling of which is critical for considering quality of production or even of the company itself. When verifying empirically the relationships between the application of quality management and company performance, it has to be taken into account that when looking for causal relationships, it is necessary to work with quality perception, not with its objective operationalization because customers evaluate quality subjectively, and this opinion is the foundation of their decision to buy, which is the basic building block of financial indicators. The best way to increase company performance is thus increasing quality which is a result of a well-realized business strategy.

The definition of quality services is more difficult as services are intangible, heterogeneous, inseparable, transitory and are not possible to be owned. Service quality is a measure of how well the service level delivered matches customer expectations (Lewis a Booms, 1983). Service quality too has been described as a form of attitude 
related, but not equivalent to, satisfaction that results from the comparisons of expectations with performance (Parasuraman, Zeithaml, Berrry, 1988). Authors (like Bittner, Bolton, Drew, Parasuraman, Zeithaml, Berrry and others) suggest that service quality and satisfaction are distinct constructs or two different categories (compare with Cronin a Taylor, 1992).

Mackay and Crompton say that service quality is the relationship between what customers' desire and what they perceive that they receive (Mackay, Crompton, 1990). Bitner defines service quality as "the consumer's overall impression of the relative inferiority/superiority of the organization and its services“ (Bitner, 1990). Parasuraman and Zeithaml define service quality as "the degree and direction of discrepancy between customer's service perceptions and expectations" (Parasuraman, Zeithaml, 2006). This is the most common definition of service quality. Generally, we can say that present definitions of service quality declare that a service is quality if it meets or exceeds customer's expectations.

In literature, two dimensions of customer perceptions of quality can be found: a technical, and a functional dimension (Kang, 2006). The technical dimension talks about what the customer received after its own manufacturing process services, this result can be objectively assessed by the customer, because of its nature which refers mostly to the technical solution of the problem. The functional dimension is based on the interaction between customers and providers, on their relationships, the way in which technical quality was given, which was transferred to the customer (customer access, appearance, responsiveness, punctuality). This second dimension provides evidence about how customer service is received.

According to Japanese philosophy, quality is zero defect - doing it right the first time (Parasuraman, Zeithaml, Berrry, 1985). Crosby defines quality as conformance to requirements (Crosby, 1979 reference from Parasuraman, Zeithaml, Berrry, 1985). This definition of quality makes the core of definition of quality according to ISO 9001 (compare with ČSN EN ISO 9001 ed. 2, 2010). Companies operating in industry perceive quality in accordance with this aforementioned and generally accepted definition, i.e. as a degree of meeting requirements by a set of inherent traits. On the other hand, the World Tourism Organization (WTO) defines product quality in the travel industry as "the sum of contributions and processes resulting from many stakeholders (private and public)." This notion includes two basic factors (assurance of safety and security) and also "a professional approach, which means doing things right at all times and meet legitimate expectations of consumers, thus helping to implement the principles contained in the Global Code of Ethics for Tourism." Although identical traits can be found in both definitions, a certain difference is apparent in understanding quality of companies operating in industry, and those operating in tourism. This different approach to quality is one of the building blocks of the empirical research presented in this article.

\section{Theoretical delineation of the issues researched}

Considering the generally known characteristics of contemporary business environment, many companies change - voluntarily or forced by circumstances - their antiquated product-oriented production to a market-oriented one. Customer is the crux of this approach; therefore, together with the change of the production concept, many 
companies also rely on implementing quality management as a tool that should connect the company vision, operating principles, production quality and satisfaction of customers' needs, which is the main priority of market economy, as it is the only way of creating a potential for surviving among competitors, as Willborn and Cheng claim (Lai, 2003).

Quality is one of the forms of product differentiation, being one of the two alternative approaches to becoming better than competitors, i.e. achieving a higher return on capital. This is either the aforementioned product differentiation, where the aim is for the customers to perceive it as unique, or the so-called cost leadership. Distinguishing oneself from the competition through quality should ideally create customer loyalty, lower the price-change sensitivity of buyers, and protect the enterprise against competitive forces which influence the profit margin negatively. Distinguishing through costs requires generating higher profit margins than the competition by reaching relatively lower production and distribution costs. A part of this margin has to be consequently reinvested in new technologies so that relatively low costs were maintained. While a producer who relies on quality attains a higher price-cost margin by price manipulation, a thrifty producer attains it by minimizing costs. Theorists claim that these two strategies are mutually exclusive. Achieving higher relative quality and achieving lower relative costs is seen as competing goals, with each demanding different resources, knowledge, and especially ways to achieve them (Hall 1980, Kiechel, 1981). The reason for this is that higher quality usually requires more expensive components of final production, less standardized processes, continuous focus on innovation and higher costs of distribution of information about the quality to the customers. To attain such a position, it is necessary that the customers perceive the exclusivity, and this position is not in accordance with the relatively high market share which - according to economic theory - is necessary to reduce average costs, and therefore utilisation of the cost-leadership strategy.

Due to this trade-off between quality and costs it is expected that higher quality will be accompanied by higher costs in most companies. At first sight, the aforementioned arguments seem convincing; however, some evidence has already appeared that the mutual exclusiveness of high quality and low costs does not have to be true, and the aforementioned strategies can be conjunctional. This evidence originated in research conducted by production analysts, who studied types of production processes as well as approaches to their management and their mutual contribution to output of high quality achieved with low costs (Fine, 1983). Fine presents an idea of a so-called quality-based learning curve. According to him, there is a sharper drop in costs in companies that have experience with high-quality production than in those that have experience with relatively low-quality output. The reason for this dwells in the fact that high-quality production is time demanding and meticulous, which ideally leads to uncovering and correcting potential defects in the production system which could otherwise remain unnoticed. Japanese production in various industries, which does not achieve low costs only by exploiting low labour costs, different capital expenses or overuse of automation, proves the fact that quality does not have to be accompanied by high costs (Fine, 1983).

Quality in tourism is very important because when visitors are satisfied with services offered, then they tend to be loyal, tend to return to the selected destination and are supposed to recommend it to others. Service quality in a tourism context has been 
viewed mostly as the quality of opportunities available at a destination, and it is considered likely to be related to a tourist's quality of experience (Crompton and Love, 1995). Quality of opportunities is the feature or attribute of a service provided by management (Crompton, Love, 1995). Production of recreational opportunities which visitor wants means more quality services.

Quality of service is the essential factor which can help tourism companies attract more customers (Beckman, Veldkamp, 1995). The main reason for the attention paid to improving service quality in tourism is that high quality pays off. Zeithaml, Parasuraman and Berry say that "excellent service pays off because it creates true customers - customers who are glad they selected a firm after the service experience, customers who will use the firm again and sing the firm's praises to others" (Zeithaml, 1990).

Quality is an elusive and indistinct construct, often mistaken for imprecise adjectives like goodnesss, luxury or weight (Crosby, 1979, reference from Parasuraman, Zeithaml, Berrry, 1985). Quality and its requirements are not easily articulated by consumers (Takeuchi a Quelch, 1983). Explication and measurement of quality also present problems for researchers (Monroe a Krishnan, 1983). While the substance and determinants of quality may be undefined, its importance to firms and consumers is unequivocal. Research has demonstrated the strategic benefits of quality in contributing to market share and return on investment as well as in lowering manufacturing costs and improving productivity (Parasuraman, Zeithaml, Berrry, 1985). The next empirical evidence also shows that implementing, controlling and measuring of service quality influences financial performance in a positive way (Maiga and Jacobs, 2005, Wruck and Jensen, 1996, Hendrick and Sighal, 1997). This is the reason why various tools on Total quality management (TQM) have been developed.

Impact of market conditions on the relationship between quality and performance is confirmed for example by studies Runduse and Chong which deals with relationship between applications of TQM, intensity of market competition and corporate performance (Chong, Rundus, 2004). On the basis of 89 questionnaires answered by production and operational managers in Australia and their analysis by the means of multiple regression use, it was shown that the higher the degree of competition in the market the more positive relationship between levels of quality characteristics and performance.

The fact that the application of TQM strategy measurably improves the performance of a company in the form of higher profit margins and growth in share prices can be found in research on a sample of 60 companies executed by Lemak, Reed and Satish (Lemar, Reed, Satish, 1997). The link between quality and performance was also examined Madu, Kuei and Jacob (Madu, Kuei, Jacob, 1996). Based on the practice of 165 managers' relationships between various measures of quality and the nine parameters characterizing organizational performance were tested. The data were divided into four categories reflecting the type of company size, age and the presence of a formal quality department in the company. On the basis of a discriminant analysis, more positive correlations between parameters of quality and performance for producting company were shown, than for companies providing services. Those who were interested in differences between manufacturing companies and providing services were also 
Johnson Nilsson and Gustafsson (Nilsson, Gustafsson, 2001). It was also shown that older managers from producting companies do not tend to perceive the relationship between the quality of products and five of the nine performance parameters such as size of market share.

So since the 1980s when the Total Quality Management (TQM) concept was first introduced, theory and practice have been trying with more or less success to confirm the positive effects of the implementation of quality management on company efficiency and performance (Santos-Vijande, Alvarez-Gonzales, 2007). Although there is a general agreement about the eight basic principles of TQM, a unified set of metrics which would measure and evaluate the success rate of TQM implementation does not exist. Hence, individual empirical studies focusing on this issue use different sets of the so-called critical factors of quality management, which in effect invalidates any comparison and generalization of the results. Moreover, these studies do not agree on a unified measure of performance, financial performance in particular where in most cases asset or capital invested profitability is used. However, it is agreed that the quality-performance relationship is influenced by uncontrollable factors from outside the company, such as the character of competition or the rate of uncertainty, as claimed by e.g. Fuentes or Chong and Rundus (Fuentes, 2004, Chong, Rundus, 2004), and internal factors of the company, such as the TQM implementation period, size of the company, rate of diversification or the company's capital intensity, as stated by Terziovski and Samson, or Taylor and Wright (Terziovski, Samson, 1999, Taylor, Wright, 2003).

However, when synthesizing outcomes of the studies published so far, it is not possible to reach unequivocally valid conclusions. Wruck and Jensen state that implementing measures that contribute to increasing quality, like lowering the defect rate or decreasing the number of customer complaints, should lead to increase in profitability (Wruck, Jensen, 1994). Garvin claims that profit and market share are positively influenced by quality (correlated with it) (Garvin, 1991). This proposition is confirmed by Hendricks and Singhal who empirically compared profitability, growth of revenue and costs of companies that received awards for quality, and of companies without such awards in a control group (Hendricks, Singhal, 1997). Confirming an intuitive assumption, indicator values of awarded companies proved to be better. Subedi and Maheshwari's study follows up on this and expands the research. They studied the difference between the performance of companies that received the Baldrige Award for quality in the years 1988 to 2003 and performance of their competitors from the same sector. It was investigated whether quality improvement results in a long-term increase in performance. Final findings revealed that the growth of income and revenues was higher in companies which received the award. These authors also study the difference in the levels of stock to verify the claim that the lean production concept and TQM are closely connected. For example, a study by Easton and Jarrell confirmed the positive effect of TQM on financial performance (Easton, Jarrell, 1998), while for example Chapman's research reached completely opposite conclusions, and there are even projects which did not find any relation between the two categories (Chapman, 1997). These are represented for example by Adam, or York and Miree (Adam, 1994, York, 2004). 
Hackman and Wageman describe the dependence of the results of quality management implementation on the degree of the implementation (Hackman, Wageman, 1995). They also found out that only $4 \%$ of 99 articles dealing with quality between the years 1989 and 1993 took this degree of implementation into account. The fact, that the degree and manner of implementation are vital for all the positive effects of TQM to fully develop, is also confirmed by surveys organized by consultancy firms (John stark associates, 2010). It is very sad that only $20 \%$ to $36 \%$ of companies that implemented the TQM concept in their businesses were able to reap the significant or even material benefits in the areas of quality, productivity, competitiveness or return on capital (Harari, 1993, John stark associates, 2010). Harari ponders the reasons which lead to the situation when even in a business environment where there is focus on quality the positive impact of TQM does not appear (Harari, 1993). He sees the reasons in a narrow focus on managing internal processes and neglecting the external environment, in concentrating on meeting the fixed minimum production standards without any attempt at adding a value, in excessive bureaucracy, in insufficient degree of delegation of authority and responsibility for quality to production workers, in lack of interdisciplinary cooperation between individual departments, in lack of acknowledging success in improving quality financially, in neglecting to establish new partnerships, in a low emphasis on innovation, in allowing the managers to pursue their personal, rather than the company's, interests, but also in the loss of employees' joy and satisfaction derived from producing quality output.

Hackman and Wageman's research also showed that the extent of the effects of TQM is influenced by the organizational structure of the company (Hackman, Wageman, 1995). Shea and Howell propose an ideal organizational structure, which should provide the necessary room for supervisory activities and at the same time is flexible enough to adapt to changes in external market environment swiftly (Shea, Howell, 1998). Douglas and Judge's research was one of the studies that considered the influence of organizational structure on the effectiveness of the TQM technique implementation, as well as the extent to which the set of all key practices of quality management was used when evaluating the benefits of TQM implementation (specifically, its connection with competitive advantage) (Douglas, Judge, 2001).

D. H. Maister was also one of those who were concerned with the significance of product quality as a key aspect of a permanently successful company (Maister, 2001). Due to the fact that Maister's study was based on international data about subsidiaries of the companies included in the research, its conclusions also reflect national peculiarities of individual business environments. One of the important findings of the study was that financial performance, which investors, creditors, and other interest groups undoubtedly follow most closely, depends mainly on production quality, but also on the quality of company climate and on the relationships with customers. The level of these two determinants then, according to Maister, depends on employee satisfaction and the socalled high company standards, which means an environment where highly qualified employees and competences and responsibility corresponding to their qualification are considered to be a standard. The results of this research then confirm the importance of quality management in a company.

Other studies that examine the influence of production quality on market share also confirm that quality improvement can have a positive impact on direct costs in some 
sectors. Specifically, they studied the possibility that production quality has an indirect influence on reduction of direct costs through its influence on the market position. According to this line of reasoning, higher quality is reflected by higher market share, which lowers direct costs due to the economies of scale (Lynn, Chang, Buzzell, 1983).

Quality management is by no means a simple affair, and as has already been pointed out, it depends on many factors which are by themselves difficult to influence and quantify. The studies conducted so far on the influence of quality management implementation on a company's financial performance have not come to a clear agreement as to the form and degree of this effect; nevertheless, despite these conclusions we still presume that quality management is and will remain a great challenge for the modern and competitive company of the $21^{\text {st }}$ century.

But to can control service quality, first it is necessary to measure it. Concept of quality is understood as the ability of a product or a service to satisfy needs, requirements and expectations of customers. Thus the customer's needs, perceived quality or customer satisfaction have become a basis for measuring services quality in particular. Many authors have approached services quality and consumer satisfaction as being synonymous (Howat, Absher, Crilley, Milne, 1996). It is evident that there exists opposite opinion on the relationship of service quality and consumers satisfaction. On the other hand, it is evident that a concrete relationship between service quality and consumer satisfaction exists. It is possible to observe that service quality and customer satisfaction relate closely together, so that service quality influences consumer satisfaction or vice versa (Taylor a Baker, 1994).

Bei and Chiao, or Namkung and Jang declare that in much research it is shown that service quality is an atendence of consumer's satisfaction (Bei, Chiao, 2001, Namkung and Jang, 2008). For example, the research about thermal tourism by Alén and Fraiz has shown that quality of the services influences consumer satisfaction (Alén, Fraiz, 2006). So measuring of service quality is mainly about measuring consumer perceptions of service quality. Measuring quality of the services is heterogenous because it is a reset of subjective judgement of customers (Bowen, 2002).

Generally, organizations can use qualitative methods (e.g. interviews, focus groups or observation) and quantitative methods (e.g. questionnaires) for measuring services quality. There are also specific tools for measuring service quality. We can mention Grönroos' model, SERVQUAL, SERVPERF, indicators of consumer satisfaction etc., or complex methods, for example the EFQM model.

Measuring service quality is difficult because of the three following features unique to services: intangibility, heterogeneity and inseparability of consumption as mentioned above. There are no objective measures so an appropriate approach for measuring service quality is based on the way consumers perceive quality of a service (Parasuraman, Zeithaml, Berry, 1988).

First of models for measuring service quality is Grönroos' model (Grönroos, 1984). This model works with technical and functional dimensions of services as mentioned in the text above. The main idea is that service quality is dependent on expected service and perceived service. Perceived quality is determined by technical and functional quality, and by corporate image. Grönroos identified seven criteria of good service 
quality - professionalism and skills, attitudes and behaviour, accessibility and flexibility, reliability and trustworthiness, service recovery, serviscape, reputation and credibility. These criteria are very similar to Parasrauman model SERVQUAL (later in the text), however, there is no mathematical representation in Grönroos' model.

The conceptualization and measurement of the service quality construct has been dominated by one of special methods called SERVQUAL which were created by Parasuraman et al. in 1988. The main idea is that consumers asses service quality by comparing their expectations of service with their perception of the service received (Accounts Commission for Scotland, 1999). When these expectations are not met, the service quality gap is created. Service quality is achieved when these expectations are met or exceeded. So for measuring service quality it is necessary to measure consumers' expectations and perceptions of services quality together. SERVQUAL defines five dimensions of quality - tangibility (the physical aspects of the service such as equipment, facilities, resources), reliability (providing consistent and precise services), responsiveness (willingness to customers), assurance which includes communications with customers, credibility of a company, security, competence of a company and courtesy of employees. The fifth dimension of service quality is defined as empathy which includes knowing the customers and individual approach. Within these five dimensions twenty-two specific aspects of quality are separately for expectations and perceptions defined and by comparison we can find the service quality gap in each dimension of service quality. Positive gap is desirable, negative gap is undesirable.

Crompton, Mackay and Fesenmaier stated that SERVQUAL is not suitable for measuring service quality because this tool was originally developed to measure general service quality. So in 1990, they developed a REQUAL model which is used to evaluate services of tourism companies (Crompton, Mackay, Fesenmaier, 1990). New evaluating scales are so defined to better reflect specifics of tourism companies. In 1992, Cronin and Taylor created SERVPERF which measures only consumer's perceptions of a service quality (Cronin, Taylor, 1992). So the difference between SERVQUAL and SERVPERF comprises of the fact that SERVQUAL searches for a gap between expectations of consumers and perceptions of a service quality but SERVPERF is interested only in consumer's perceptions.

Most recently, a hierarchical and multidimensional model is created by Brady and Cronin (Brady, Cronin, 2001). They defined three primary dimensions which create overall service quality - personal interaction quality, physical environment quality and outcome quality. Each of these dimensions is created by three subdimensions. Personal interaction quality consists of attitude, behavior and experience, physical environment quality consists of ambient conditions, design and social factors and outcome quality consists of waiting time, tangibles and valence. This model helps manager to understand what defines service quality perceptions, how these are formed and that it is of a great importance where the service experience takes place.

Models mentioned above have a universal application, and are appropriate for different types of services. Most studies which focused on service quality in the tourism industry have measured service quality by using SERVQUAL (Caro, Garcia, 2008).

The results of measuring consumer satisfaction have been often published in the indexes such as the Swedish customer satisfaction index since 1989, American customer 
satisfaction index (ASCI) since 1994, or European customer satisfaction index (ECSI) since 1999. (Johnson, Gustafsson, Andreassen, Lexik, Cha, 2000). Indexes follow specific areas which have a decisive influence on customer satisfaction; for example the most recent index follows corporate image, consumer expectations, perceived quality, perceived value and customer loyalty.

Generally, in service quality we can define two lines of thoughts on this measuring - an American and a European perspective (Kang, James, Alexandris, 2002). The American perspective focuses on functional dimension of quality whilst the European perspective focuses on two or more components. In conclusion, we can see that there has been no consensus as regards the measure of service quality.

This study agrees with the European line of measuring service quality because we believe that in the measurement of service quality it is necessary to monitor their functional and technical dimension together, and it is not possible to ignore one of them ignore. The final product can not be assessed without taking into account the number of items needed and the level of their implementation (abstracting from the technical dimension of service quality).

At the end, we can mention that in measuring service quality there also exist methods which reflect not only customer's perception of quality but monitor behavior of company to all its stakeholders. Total quality management (TQM) is the base for these methods. These models serve for measuring quality of company as a whole. To measure the quality of tourism services, it is very suitable to apply these methods of total quality management which take into account overall satisfaction of all stakeholders, such as consumers, service providers and local population (Vajčnerová, Ryglová, 2010). For tourism companies the EFQM (European foundation quality model) model is very suitable. "The excellence models provide frameworks based predominantly on the perspective of the firm, not that of the client, but when they attempt to establish the positive consequences on performance of some quality practices, they consider customers' results among the measures of performance" (Hernández-Maestro and Muñoz-Gallego andSantos-Requejo, 2009).

In this study we decided to evaluate quality in terms of the provider, not the client, because this approach is better feasible from our position, even though we believe that we would be unable to identify any specific customer of companies. On the other hand, we recognize the sacrifice of some degree of accuracy in the responses received because the companies' looking at the quality level can be vastly different from the perception of quality of their clients.

\section{Research methodology}

A questionnaire method was used for this research. The questionnaire contained a general part, which focused on a more detailed identification and classification of the company, including questions connected with ways of monitoring quality and with the relationship between quality and competitiveness of the company, and the main part, which consisted of ten closed questions - four of them in the scale form, and the remaining six offering selected characteristics of the quality of a company. The questionnaire survey was conducted during the year 2009 and at the beginning of 2010. 
The sample surveyed contained 31 tourism companies and 105 companies from different sectors. The total number of companies that provided the data amounted to 136 . Companies in the tourism sector were represented mainly by accommodation and catering companies (18 companies) and by transport companies (11 companies), next were included companies with activities of travel agencies ( 1 company) and with recreational, cultural and sports activities (1 company). Other sectors were represented mainly by manufacturing companies (40 companies), trade companies (19 companies), building companies (11 companies), to a lesser extent then mining companies, food manufacturing, financial intermediation, information technology etc.

Location of companies from the tourism sector and other industries was uniform as the most companies were located in the South Moravia Region (41\% of companies), in Prague (17\% of companies), in the Vysočina Region (9\% companies) and in the Olomouc Region, in the Moravian-Silesian Region and the Zlín Region (identically 7\% of companies). A smaller number of companies came from the other regions of the Czech Republic.

According to legal forms of business in both samples of companies limited liability companies (57\% of companies) were the companies represented most often, and these were followed by joint stock companies (38\% of enterprises); the remainder were cooperatives and state companies. Although the structure of both samples is not the same like the structure of companies in the economy of the Czech Republic, essential comparability of companies was ensured thanks to the uniform distribution of companies in both samples.

Both samples have similar structure if sorted by number of employees as well. It could be demonstrated (in line with the next chart) that the shares of four basic size degrees are in both samples pretty much the same - micro enterprises (less than 10 employees) are in both groups represented by approximately 8\%, small companies (10 - 49 employees) by $32 \%$, medium sized enterprises $(50-249$ employees) by $32 \%$ and large companies (over 250 employees) nearly by 30\%. On the basis of the previous paragraphs it could be assumed that both samples are comparable and suitable for further analysis.

\section{Chart 1: Structure of the samples sorted by number of employees}

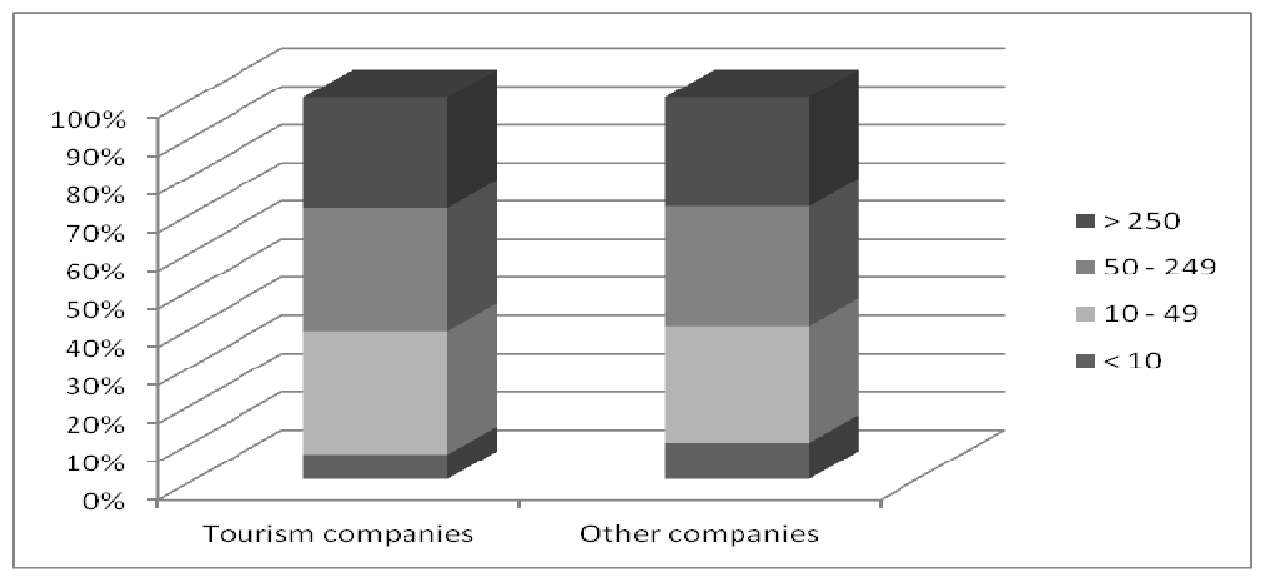


The answer analysis uses traditional statistical methods of univariate and bivariate analyses. As our research concentrates on searching for the specifics of the tourism sector, it is vital to define the respondents from the sector clearly and precisely. The NACE classification was used to achieve this. Companies with these classifications were included in the group of companies from the tourism sector:

- 550000 Accommodation and food service activities

- 490000 Land transport and transport via pipelines

- 510000 Air and space transport

- 790000 Support activities for transportation; Travel agency activities

- 930000 Recreational, cultural and sports activities

The group of companies from different sectors consisted of companies from other than the aforementioned categories of the sector classification of economic activities.

The comparisons in the following chapters are based on crosstabs, i.e. identification of different frequencies of occurrence of the phenomena in the groups of companies that were studied. Although our sample of respondents is rather small, we deemed it important to examine the general validity of the causalities that appeared. The test of statistical significance of the potential differences is the simplest guide in this area. Due to this, every table that follows has information about the (potential) statistical significance of the differences between the frequencies of occurrence of the answers or their averages. Statistical significance is measured in accordance with traditional methods, using the classic measures of associations - beside the basic chi-square test of significance (for frequency of occurrence) and t-test (for averages), we use other measures such as Sommer's d, Goodman and Kruskal tau, Cramer's v, or Kendall's tau.

Special attention was paid to multiple response questions, which are questions where the questioned had the possibility to check several options. In this case, it was necessary to evaluate the percentages of each of the answers separately, and only then calculate the relative significance using all the answers. There were two possible approaches express the significance of the particular option in relation to all respondents, or the significance of the option in relation to all responses (the number of which is higher, because every respondent could choose more than one option). As we were more interested in the respondents - the companies - we used the first approach. The results of multiple response questions, presented in the following chapters, are always related to the respondents as a whole. For example, in the first line of Table 1, the value $73.3 \%$ given for the option "Product/Service quality" means that product/service quality is perceived as an advantage by $73.3 \%$ of the tourism companies (as opposed to the $69.8 \%$ in other sectors).

To examine the financial situation of companies, a financial analysis method was used, in particular the ratio analysis of indicators which were chosen in line with the literature review mentioned above. The indicators were chosen to enable assessment of all the important parts of the business, i.e. profitability, activity, debt and liquidity; in other words, to facilitate the understanding of the complex financial situation of the company. The construction of the chosen indicators is based on the previous research of the authors (for more information see e.g. Suchánek, P., Evaluation of economic performance of cooperatives in the Czech Republic, 2008) and uses the methodology of 
the Czech Ministry of Industry and Trade in order to be able to compare the resulting values with sector averages.

These financial indicators were then contrasted with the aforementioned qualitative characteristics provided by the questionnaire survey. In this case, it was mainly comparing consistency or differences of average values of the indicators in relation to the various types of questions, or characteristics of companies. As in the previous part, statistical significance of these differences was tested here, too, using standard statistical tests (especially the t-test).

\section{Results of the company quality evaluation}

As stated in the previous chapters, the topic of this research was quality and its company management aiming at achieving a higher level of performance and competitiveness. To verify this initial proposition - that quality is the key factor in performance and competitiveness among companies, the questionnaire included two questions which asked the company to state their advantages over the competitors. The exact wording of the first question and the evaluation of answers given to it are shown in the following table.

Table 1: Competitive advantages of the company which improve its position in the market

\begin{tabular}{|l|c|c|}
\hline & Tourism companies & Other companies \\
\hline Product / service quality & $73.3 \%$ & $69.8 \%$ \\
\hline Competence / professionalism & $53.3 \%$ & $45.8 \%$ \\
\hline Tradition & $46.7 \%$ & $39.6 \%$ \\
\hline Contacts / relations & $60.0 \%$ & $43.8 \%$ \\
\hline Flexibility & $30.0 \%$ & $41.7 \%$ \\
\hline Location & $40.0 \%$ & $14.6 \%$ \\
\hline Technology & $30.0 \%$ & $25.0 \%$ \\
\hline Personal approach & $26.7 \%$ & $19.8 \%$ \\
\hline
\end{tabular}

Source: the authors

The fact that according to the companies quality is the most significant competitive advantage was supposed to be confirmed by a question placed at the very end of the questionnaire.

Table 2: Advantages of the company over the competitors

\begin{tabular}{|l|c|c|}
\hline & Tourism companies & Other companies \\
\hline Quality & $93.1 \%$ & $71.3 \%$ \\
\hline Tradition & $65.5 \%$ & $43.6 \%$ \\
\hline Contacts & $48.3 \%$ & $37.6 \%$ \\
\hline Flexibility & $37.9 \%$ & $42.6 \%$ \\
\hline Other & $17.2 \%$ & $36.6 \%$ \\
\hline
\end{tabular}

Source: the authors 
Here it is necessary to repeat the already defined fact that quality is not determined by the objective technological and material side only, but to a great extent also by the consumer's subjective perception of quality (satisfaction with the product or service). Thus it was important to find out whether individual companies survey this satisfaction.

The next table overviews selected companies' attitudes towards research questions. We derive from the prediction that should quality be as paramount a competitive advantage as the previous tables show, it is desirable to examine how companies assess the level of their product or service quality. Since we found out that companies examine customer satisfaction (90 per cent of the tourism companies do surveys), then the question of the measure of customer satisfaction should also be asked.

Other question is - in cases when customer satisfaction does not reach product or service quality assessment in terms of technological design, or in other words, if the technological sophistication of the product is on a higher level than the overall customer satisfaction - if this technologically defined quality is in accordance with the needs of the consumer, i.e. to what extent the product or service are adapted to customer's requirements.

Finally, we tried to estimate the degree of customer satisfaction of the two groups of companies and the reasons why this situation occurred. Nevertheless, the effort to reach customer satisfaction is not an end but only a means to achieving long-term prosperity of a company facilitated by its competitiveness. An important question then arises: to what extent do companies see a connection between customer satisfaction and their competitiveness.

Table 3: Selected characteristics regarding the quality measurement and evaluation

\begin{tabular}{|l|c|c|c|c|c|c|c|}
\hline & Company & Maximum & Significant & Medium & Little & Minimum & $\begin{array}{c}\text { p- } \\
\text { value }\end{array}$ \\
\hline $\begin{array}{l}\text { Assessment of the } \\
\text { product (service) } \\
\text { regarding quality, or its } \\
\text { technological } \\
\text { construction / design }\end{array}$ & Tourism & $29.0 \%$ & $45.2 \%$ & $25.8 \%$ & $0.0 \%$ & $0.0 \%$ & 0.031 \\
\cline { 2 - 8 } & Other & $48.6 \%$ & $41.9 \%$ & $9.5 \%$ & $0.0 \%$ & $0.0 \%$ & $0.0 \%$ \\
\hline $\begin{array}{l}\text { Customer satisfaction } \\
\text { with the product or } \\
\text { service }\end{array}$ & Tourism & $33.3 \%$ & $59.0 \%$ & $6.7 \%$ & $1.0 \%$ & $0.0 \%$ & 0.140 \\
\cline { 2 - 8 } & Other & $16.1 \%$ & $58.1 \%$ & $25.8 \%$ & $0.0 \%$ & $0.0 \%$ & 0.009 \\
\hline $\begin{array}{l}\text { Degree of adapting the } \\
\text { product (service) to the } \\
\text { requirements of the } \\
\text { customer }\end{array}$ & Tourism & $22.6 \%$ & $51.6 \%$ & $19.4 \%$ & $3.2 \%$ & $3.2 \%$ & \\
\cline { 2 - 8 } & Other & $56.2 \%$ & $32.4 \%$ & $9.5 \%$ & $1.9 \%$ & $0.0 \%$ & 0.038 \\
\hline $\begin{array}{l}\text { Strength of } \\
\text { interdependence of } \\
\text { customer satisfaction } \\
\text { and company } \\
\text { competitiveness }\end{array}$ & Tourism & $29.0 \%$ & $22.6 \%$ & $35.5 \%$ & $3.2 \%$ & $9.7 \%$ & \\
\cline { 2 - 8 } & Other & $44.8 \%$ & $28.6 \%$ & $20.9 \%$ & $4.8 \%$ & $0.9 \%$ & \\
\hline
\end{tabular}

Source: the authors 
From the previous two questions (especially from the table 2) it is clear that quality is the key factor determining competitive advantages of a company and companies do realize this fact. It can then be assumed that they attempt to implement a systematic quality management. To what extent they really do can be seen in the following table.

Table 4: Existence of a systematic product / service quality management in the company

\begin{tabular}{|l|c|c|}
\hline & Tourism companies & Other companies \\
\hline Yes & $67.7 \%$ & $80.9 \%$ \\
\hline No & $32.3 \%$ & $19.1 \%$ \\
\hline
\end{tabular}

Differences are statistically significant $(p=0,097)$

Source: the authors

In the context of the previous table, it is necessary to point out that there is a significant difference between the statement of existence of quality management and a truly implemented quality system. In other words, because of legislation, conditions of public competitions and other forms of the competitive struggle, companies often have to own a certificate of quality management. Owning the certificate, however, does not mean a real implementation in company operations. Hence, the following question examined the rate of true utilization of the quality management certificates.

Table 5: Manner of utilization of the quality management certificate

\begin{tabular}{|l|c|c|}
\hline & Tourism companies & Other companies \\
\hline Exists only on paper & $33.3 \%$ & $2.5 \%$ \\
\hline Minimum utilization & $8.3 \%$ & $0.0 \%$ \\
\hline Partial utilization & $25.0 \%$ & $27.5 \%$ \\
\hline Great extent of utilization & $33.3 \%$ & $32.5 \%$ \\
\hline Complete utilization & $0.0 \%$ & $37.5 \%$ \\
\hline
\end{tabular}

Source: the authors

The results of both groups of companies, which were acquired from the questionnaires, were ultimately set into the context of the financially expressed performance of a company, which enabled the verification of the true situation of both groups of companies regarding their success rate in the market.

Table 6: Average financial indicators in the year 2007 (per cent)

\begin{tabular}{|l|c|c|c|}
\hline & Tourism companies & Other companies & p-value \\
\hline ROA & 8.4 & 10.9 & 0,346 \\
\hline ROE & $\mathbf{1 8 . 7}^{*}$ & $\mathbf{1 7 . 8}^{*}$ & 0,063 \\
\hline Asset turnover & $\mathbf{2 . 4}^{*}$ & $\mathbf{1 . 8}^{*}$ & 0,101 \\
\hline Shareholders' equity quota & 0.51 & 0.41 & 0,925 \\
\hline
\end{tabular}

Starred values are statistically significantly different (90\% level)

Source: the authors 


\section{Discussion}

Questions aimed at defining the significance of individual factors influencing the company's competitiveness were placed at the beginning and also at the end of the questionnaire. In both cases, i.e. at the beginning, without any knowledge of the context of the questionnaire, and at the end, after answering many interconnected questions, the companies defined "product or service quality" as the most significant factor. In both cases the tourism companies attached greater weight to this factor. At the same time, they also attributed greater importance to location and personal approach, which is understandable if we consider that this group includes, among others, owners of hotels and restaurants, location and capable staff of which represent a significant aspect of success. Nevertheless, the key fact for further analysis of the results is that from the point of view of the companies themselves, quality is the most significant advantage.

In this context, it is very interesting that although tourism companies in the competitive struggle bet on quality, at the same time they only categorize their service quality as "significant" ( $45 \%$ of the tourism companies). On the other hand, companies from other sectors deem their product quality to be maximum (48.6\% of other companies). These facts reveal a certain shortcoming in the general level of service quality in tourism, when even quality that does not reach its maximum can be seen as a competitive advantage.

The assessment of customer satisfaction as subjective quality perception by the companies operating in tourism rings even more negative. Tourism companies think that most customers are significantly satisfied $(58.1 \%)$. Other companies are more positive in relation to this indicator too $-33.3 \%$ state maximum customer satisfaction. It is important to note that customer satisfaction assessment (which is conducted by $90 \%$ of tourism companies), i.e. the degree of quality from the consumer's point of view, results in even lower figures than in the case of assessment of the technological and material side of quality. In other words, companies define their service quality as their main competitive advantage, and at the same time they have problems with its technical realization and even more with its subjective evaluation by a consumer.

The fact that subjective perception of the service by a customer is, from the company's point of view, worse than the technological side of quality most probably results from the fact that vast majority of tourism companies see shortcomings in the degree of adapting their services to the customer's needs (77.4\%). Companies from other sectors answer the question in the opposite way - most of them $(56.2 \%)$ consider their product to be adapted to their customer's requirements completely.

Most probably, tourism companies do not attempt to fully satisfy the desires of their customers because they do not see a strong connection between a customer's satisfaction and their own competitiveness - most only see an average connection $(35.5 \%)$, almost $10 \%$ see it as minimum! Considering the fact that tourism companies mostly operate in the service sector, these results are very surprising and reveal great shortcomings in the overall service quality, and also in the competition in this sector. The startling assessment of the interdependence of customer satisfaction and the tourism company's competitiveness is emphasized by the results of the second group, consisting of companies from other sectors. These mostly see the interdependence as maximum $(44.8 \%)$, while only a few companies assess it as under average (5.7\% of companies). 
The fact that lower level of quality and customer satisfaction does not represent a great problem for tourism companies is confirmed by the assessment of the development of competitiveness in the past five years, which is relatively similar for both groups -19.4 $\%$ of tourism companies state that it grew significantly (11.4\% of the other companies), $51.6 \%$ think that it grew (61.9\% of the other companies). This implies that quality perception is in general different in tourism companies than in companies operating in the other sectors, and so the general substandard product and service quality does not prevent the tourism companies from increasing their competitiveness within their sector.

The importance of quality as a tool in competition is confirmed by the question that followed; it examines the significance of individual factors in the aforementioned trend of the development of competitiveness - again, product or service quality was chosen as the most significant determinant. Important external influences such as the financial crisis or the Czech Republic becoming a member of the European Union were marked as insignificant in this assessment - financial crisis was seen as having any influence by only $20.8 \%$ of the tourism companies and $16.8 \%$ of the other companies. Joining the European Union did not mean any changes for $52.4 \%$ of the tourism companies and $48.3 \%$ of the companies from other sectors.

If companies really attach such weight to the aspect of product quality, it is understandable to expect that they systematically manage quality and thus strengthen their market position. However, this area also showed specific characteristics of the tourism sector - only $67.7 \%$ of companies claimed that they manage product or service quality systematically, as opposed to $80.9 \%$ of companies from other sectors. Again, a certain disregard for strategic management and systematic approach to the allegedly key factor of competitiveness has manifested itself in the tourism sector.

However, the question that followed - to what extent the companies truly implement certificates of quality, if they own any - presents a real problem. While for companies from other sectors it is unthinkable to have these standards only "on paper," i.e. not to implement them in company operations (only 2.5\%), it is normal for the tourism companies to have the standards formally, but not use them in everyday business. None of the questioned companies from this sector answered that they use the certificates completely. A whole one third of these companies admitted to having the certificate only on paper $(33.3 \%)$. Using the certificate to a great extent was the choice of another third $(33.3 \%)$ - if we place this fact in the context of the previous question, we find that of the $67.7 \%$ of the tourism companies that claim they manage quality systematically, none implemented the standards completely and only one third utilizes them to a great extent. This means that only approximately a quarter of the companies utilize the quality management certificates - the factor that almost all the tourism companies claim to be the most significant competitive advantage. If we consider the fact that this category includes companies that are subject to hygiene quality standards (e.g. HCCP), then this conclusion is extremely startling, especially when compared with the companies from other sectors, almost all of which implemented the quality management certificates in their operations at least partially.

Despite these negative facts it is necessary to point out that in terms of the financial performance, tourism companies' fare quite well compared with the companies from 
other sectors. There are even many indicators for which they reach better figures than the other companies, which have slightly higher profitability of the overall capital.

When comparing the theoretical assumptions and the conclusions, we can see that it the factwhich many authors have declared in the theoretical part (eg, Beckham, Zeithaml, Parasuman, etc.), i.e. that quality is one of the key factors of success of a company (at least in companies' perception) has been confirmed.

It has been shown that tourism companies are placing particular emphasis on technological dimension of quality, while companies in other sectors are also trying to adapt the product to the customer view. According to many authors (e.g. Wruck, Garvin, Hendricks, Subedi, Lemak, etc.) the application of quality management is associated with growth and better financial results, however, it has been shown that tourism companies have declared that in the past five years they have grown in spite of a lower quality level, or a small adjustment of the product to the customers. Even tourism companies in some areas showed better financial results than the companies from other sectors, although these companies provide a better product adjustment to the customers.

\section{Conclusion}

The research into the perception of quality in tourism companies and the following comparison with a sample of companies from other sectors brought several highly interesting findings which are reinforced by the fact that many of the questions analysed produced statistically significant answers.

The fact that tourism companies really consider the factor of quality to be the key determinant of their success (in accordance with contemporary theory, mentioned in the theoretical part of the article) is the initial finding of the analysis. The fact that the companies stressing their product or service quality achieve better results in financial analyses compared with companies from other sectors also fits the theoretical framework. This, however, is the point where the harmony between theory and the findings of our research ends.

The level of the real quality management in tourism companies represents the crucial problem. These companies may proclaim that quality is their key competitive advantage; however, our research has proven that in reality, they do not implement quality management systems. Many studies mentioned in the theoretical part of this text have proven that without a perfect or near-perfect quality management, a positive impact on the company's competitiveness cannot be expected.

In this context, it is necessary to mention that tourism companies, as opposed to the companies from other sectors, only see a low connection between customer satisfaction (meaning product quality) and competitiveness of the company itself. This finding is vital for understanding the results of our study. Tourism companies proclaim emphasis on quality of their services to keep and improve their reputation; nevertheless, they feel that in the current state of competition, they can reach satisfactory financial results even with services that are not fully adapted to customers' needs, or with services that do not attain maximum quality possible. In accordance with the presented theory, a question of whether these companies, which do not endeavour to maximize quality, prefer the strategy of minimizing the cost of their service, i.e. the cost-leadership strategy. However, the research has shown that the price, or rather the lower costs, was not 
mentioned in the answers to the questions about competitive advantages at all, or to a very low extent. It can therefore be concluded that companies do not attempt to gain any competitive advantage through price but really through quality, however questionable it might be.

From the aforementioned facts it can be concluded that consumers do not demand from tourism companies such preciseness as from companies from other sectors, and find even lower quality satisfactory - these companies then:

- do not perceive a strong connection between customer satisfaction and their competitiveness like other companies do;

- can see their service quality as a competitive advantage, even though they feel the quality could be improved;

- $\quad$ are not pressured into systematic quality management and into real implementation of quality certificates in their operations;

- can achieve an increase in competitiveness despite worse assessment of their product or service quality;

- can achieve excellent financial results in spite of all the aforementioned points.

\section{Research limitation and further research suggestions}

General applicability of the results and conclusions mentioned is limited of several factors. The structure of research sample, which is not the same as the structure of companies in the Czech economy, may be seen as the first one. It decreases validity of the results. Moreover, this factor supports a size of samples because the number of enterprises verges on the border of acceptability. Objectivity of the results discovered is the next problem as the point of view of subjective respondents (enterprises) on the research problem is the issue. The questionnaire is built to find out if the data of respondents are misrepresented by companies but it was not possible to correct the discovered distortion.

Further research suggestion is to better structure the samples of companies in order to compare individual sectors among each other; also, it would be appropriate to increase the total number of companies in the samples. It is important to arrange higher objectivity of results but this we found to be the most difficult assignment. We believe that it would be appropriate to enrich the research with consumers' point of view. This would lead to a complex appraisal of quality of Czech enterprises. In this case, a problem may arise as of how to address customers of individual enterprises. It is possible to make quality research between customers generally but it is a question if these results will be comparable and connectable with research results in enterprises. Therefore we assume, that an integral ratio of quality (as an enterprise quality measure) could be constructed and then with integral ratio of enterprise performance compared. 


\section{References}

Accounts Commission for Scotland. Can't get no satisfaction? Using a Gap Approach to Measure Service Quality. 1999. Retrieved from: http://www.auditscotland.gov.uk/docs/local/2000/nr_000627_GAP_service_quality.pdf .

ADAM, E. E. (1994). Alternative quality improvement practices and organizational performance. Journal of Operations Management. Vol. 12, No. 1, pp. 27-44.

ALE`N GONZA'LEZ M. E., FRAIZ BREA J. A. (2006). Evaluacio'n de la relación existente entre la calidad de servicio, la satisfacción y las intenciones de comportamiento en el ámbito del turismo termal. Revista Europea de Dirección y Economı́a de la Espresa. Vol. 15, No. 3, pp. 171-184.

BACKMAN, S. J., VELDKAMP, C. (1995). Examination of the Relationship between service quality and user loyalty. Journal of Park and Recreation Administration. Vol. 13, No. 2, pp. 29-41.

BADE, F. J. (1986). The Economic Importance of Small Business and Medium Firms in the Federal Republic of Germany, New Firms and Regional Development in Europe, London: Croom Helm, pp. 256-274.

BARNEY, J. (1991). Firm Resource and Sustained Competitive Advantage, Journal of Management. Vol. 17, No.1, pp. 99-120.

BEI, L. T., CHIAO Y. C. (2001). An integrated model for the effects of perceived product, perceived service quality and perceived price fairness on consumer satisfaction and loyalty. Journal of Consumer Satisfaction, Dissatisfactiona and Complaining Behaviour. Vol. 14, pp. 125-140.

BIRLEY, S.; WESTHEAD, P. (1990). Growth and Performance Contrasts between Types of Small Firms, Strategic Management Journal. Vol. 11, No. 7, pp. 535-557.

BITNER, M., BOOMS, B., TETREAULT, M. (1990). The Service Encounter: Diagnosing Favorable and Unfavorable Incidents. Journal of Marketing. Vol. 54, pp. 71-84.

BLAŽEK, L. et al. (2009). Konkurenční schopnost podniků. Analýza faktorů hospodářské úspěšnosti. Druhá etapa. Brno: Masarykova univerzita. 1. vyd. ISBN 97880-210-5058-7.

BOWEN, D. (2002). Research through participant observation in tourism: A creative solution to the measurement of consumer satisfaction/dissatisfaction (CS/D) among tourists. Journal of Travel Research. Vol. 41, No. 1, p. 4.

BRADY, M. K., CRONIN, J. J. (2001). Some new thoughts on conceptualizing perceived service quality: a hierarchical approach, Journal of Marketing. Vol. 65, pp. 34-49.

CARO, L. M., GARCIA, J. A. M. (2008). Developing a multidimensional and hierarchical service quality model for the travel agency industry. Tourism Management. Vol. 29, Iss. 4, pp. 706-720. 
CROMPTON, J. L., LOVE, L. L. (1995). The predictive validity of alternative approaches of evaluating quality of a festival. Journal of Travel Research. Vol. 34, pp. 11-24.

CROMPTON, J. L., MACKAY, K. J., FESENMAIER, D. R. (1991). Identifying dimensions of service quality in public recreation. Journal of Park and Recreation Administration. Vol. 9, Iss. 3, pp. 15-27.

CRONIN, J. J., TAYLOR, S. A. (1996). Measuring service quality: a reexamination and extension. Journal of Marketing. Vol. 56, pp. 55-68.

CROSBY, P. B. (1979). Quality is free: The art of making quality certain. McGraw Hill Custom Publishing: New York, 309 p. ISBN 0070145121.

ČSN EN ISO 9001 ed. 2, 2010.

DAVIDSON, P. (1991). Continued Entrepreneurship: Ability, Need and Opportunity as Determinants of Small Firm Growth, Journal of Business Venturing. Vol. 6, pp. 405429.

DENISON, D. R., ALEXANDER, J. M. (1986). Patterns and Profiles of Entrepreneurs: Data from entrepreneurship Forums. Frontiers of Entrepreneurship Research, Babson College. pp. 578-593.

DOLLINGER, M. J. (1985). Environmental Contacts and Financial Performance of the Small Firm. Journal of Small Management. Vol. 23, No. 1, pp. 24-30

DOUGLAS, T. J., JUDGE, W. Q. (2001). Total quality management implementation and competitive advantage: the role of structural control and exploration. Academy of Management Journal. Vol. 44, No. 1, pp. 158-169.

DUCHESNEAU, D. A.; GARTNER, W. B. (1990). A Profile of New Venture Succes and Failure in an Emerging Industry. Journal of Business Venturing. Vol. 5, pp. 297312.

EASTON, G. S., JARRELL, S. L. (1998). The effects of total quality management on corporate performance: an empirical investigation. Journal of Business. Vol. 71, No. 2, pp. 253-307.

FROST, B. (1999). Performance metrics: The new strategic discipline. Strategy and Leadership. ABI/INFORM Global. Vol. 27, No 3, p. 34.

FUENTES-FUENTES, M. M., ALBACETE-SÁEZ, C. A., LLORÉNS-MONTES, F. J. (2004). The impact of environmental characteristics on TQM principles and organizational performance. Omega. Vol. 32 No. 6, pp. 425-442.

GARVIN, D. A. (1984). What does product quality really mean? Sloan Management Review. Vol. 26, No.1., pp. 25-43.

GARVIN, D. A. (1987). Competing on the eight dimensions of quality. Harvard Business Review. Vol. 65, No. 6, pp. 101-109.

GARVIN, D. A. (1991). How the Baldrige Award Really Works. Harvard Business Review. Vol. 69, No 6, pp. 80-94. 
GRÖNROOS, C. (1984). A service quality model and its marketing implications. European Journal of Marketing. Vol. 18, No. 4, pp. 36-44.

HABER, S., REICHEL, A. (2005). Identifying Performance Measures of Small Ventures - The Case of the Tourism Industry. Journal of Small Business Management, Vol. 43, No. 3, pp. 257-286.

HACKMAN, J., WAGEMAN, R. (1995). Total quality management: empirical, conceptual and practical issues. Administrative Science Quarterly, Vol. 40, pp. 309-42.

HALL, W. K. (1980). Survival Strategies in a Hostile Environment. Harvard Business Review. Vol. 58, pp.75-85.

HARARI, O. (1993). Ten reasons why TQM doesn't work. Management Review. Vol 82, No. 1, ABI//NFORM Global, pg. 33.

HENDRICKS, K. B., SINGHAL, V. R. (1997). Does Implementing an Effective TQM Program Actually Improve Operating Performance? Empirical Evidence from Firms that have Won Quality Awards. Management Science. Vol. 43, Iss. 9, pp. 1258-1274.

HERNÁNDEZ-MAESTRO, R. M., MUÑOZ-GALLEGO, P. A., SANTOS-REQUEJO, L. (2009). Small Business Owners'Knowledge and Rural Tourism Establishment Performance in Spain. Journal of travel resech. Vol. 48, No. 1, pp. 58-77. DOI: $10.1177 / 0047287508328794$.

HOWAT, G., ABSHER, J., CRILlEY, J., MILNE, I. (1996). Measuring customer service quality in sports and leisure centres. Managing Lemure. Vol. 1, No. 1, pp. 7789.

CHAPMAN, R. L., MURRAY, P. C., MELLOR, R (1997). Strategic quality management and financial performance indicators. International Journal of Quality and Reliability Management. Vol. 14, No. 4, pp. 432-448.

CHONG, V. K., RUNDUS, M. J. (2004). Total quality management, market competition and organizational performance. The British Accounting Review, Vol. 36, No. 2, pp. 155-172. DOI: 10.1016/j.bar.2003.10.006.

JOHANNISSON, B (1993). Designing supportive contexts for emerging enterprises, Small Business Dynamics: International, National and Regional Perspectives London: Routledge.

JOHNSON, M. D., GUSTAFSSON, A., ANDREASSEN, T. W., LERVIK, L., CHA., J. (2000). The evaluation and future of national customer satisfaction index models. Journal of Economic Psychology. Vol. 22, No. 2, pp. 217-245.

KALLEBERG, A. L.; LEICHT, K. T. (1991). Gender and Organzational Performance: Determinants of Small Business Survival and Succes, Academy of Management Journal. Vol. 34, No 1, pp. 136-161.

KANG, G. D. (2006). The hierarchical structure of service quality: integration of technical and functional quality. Managing Service Quality. Vol. 16, No. 1, pp. 37-50. DOI: $10.1108 / 09604520610639955$ 
KANG, G. D., JAMES, J., ALEXANDRIS K. (2002). Measurement of internal service quality: application of the Servqual battery to internal service quality. Managing Service Quality. Vol. 12, No. 5, pp. 278-291. DOI: 10.1108/09604520210442065

KEAN, R, GASKILL, L.; LEISTRITZ, L., JASPER, C., BASTOW-SHOOP, H., JOLLY, L., STERNQUIST, B. (1998). Effects of Community Characteristics, Business Environment and Competitive Strategies on Rural Retail Business Performance, Journal of Small Business Management. Vol. 36, No. 2, p. 45-57.

KIECHEL, W. (1981): Three (or Four, or More) Ways to Win. Fortune. Vol. 104, pp. $181-184$.

LAI, K (2003). Market orientation in quality-oriented organizations and its impact on their performance. International Journal of Production Economics. Vol. 84., Iss. 1, pp. 17-34. DOI: 10.1016/S0925-5273(02)00382-1

LARSEN, M. A. (2003). TQM and Organizational Performance Improvement. International Journal of Production Economics. Vol. 84, pp. 17-34.

LEMAK, D. J., REED, R., SATISH, P. K. (1997). Commitment to total quality management: Is there a relationship with firm performance? Journal of Quality Management. Vol. 2, Iss. 1, pp. 67-86.

LERNER, M., HABER, S. (2001). Performance Factors of Small Tourism Ventures: The Interface of Tourism, Entrepreneurship and the Environment, Journal of Business Venturing. Vol. 16, pp. 77-100. DOI: 10.1016/S0883-9026(99)00038-5.

LEWIS, R. C., BOOMS, B. H. (1983). The marketing aspect of service quality. Emerging perspectives on services marketing. Chicago: American Marketing, pp. 99107.

LOSCOCCO, K. A.; LEICHT, K. T. (1993). Gender, Work-Family Linkages and Economic among Small Business Owners, Journal of Marriage and The Family. Vol. 5, pp. $875-887$.

LYNN W. P., CHANG D. R., BUZZELL, R. D. (1983). Product Quality, Cost Position and Business Performance: A Test of Some Key Hypotheses. The Journal of Marketing, Vol. 47, No. 2, pp. 26-43.

MACKAY, K. J., CROMPTON, J. L. (1990). Measuring the quality of recreation services. Journal of Park and Recreation Administration. Vol. 8, No. 3, pp. 47-56.

MADU, C. N., KUEI C. H., JACOB, R. A. (1996). An empirical assessment of the influence of quality dimensions on organizational performance. International Journal of Production Research. Vol. 34, No. 7, pp. 1943-1962.

MAIGA, A. S., JACOBS, F. A. (2005). Antecedents and Consequences of Quality Performance. Behavioral Research in Accounting. Vol. 17, pp. 111-131.

MAISTER, D. H. (2001). Practice what you preach: What managers must do to create a high achievement culture. The free press. New York. London. Toronto. Sydney. Singapure. ISBN. 0-7432-1592-3. 
MILlER, A., WILLSON B., ADAMS M. (1988). Financial Performance Patterns of New Corporate Ventures: An Alternative to Traditional Measures, Journal of Business Venturing. Vol. 3, No. 4, pp. 287-299.

MOHR, J., SPEKMAN, R. (1994). Characteristics of Partnership Succes: Partnership Attributes, Communication Behavior and Conflict Resolution Techniques, Strategic Management Journal. Vol. 15, pp. 135-152.

MORRISON, A., TEIXERA, R. (2004). Small business performance: a tourism sector focus. Journal of Small Business and Enterprise Development, Vol. 11 Iss: 2, pp.166173, DOI: 10.1108/14626000410537100.

MONROE, K. B., KRISHNAN, R. (1983). The effect of price on subjective product evaluations. Blackburg: Virginia polytechnic institute, working paper.

NAMKUNG Y., JANG, S. (2008). Are highly satisfied restaurant customers really different? A quality perception perspective. International Journal of Contemporary Hospitality Management. Vol. 20, No. 2, pp. 142-155, DOI: 10.1108/09596110810852131.

NILSSON L., JOHNSON, M. D., GUSTAFSSON, A. (2001). The impact of quality practices on customer satisfaction and business results: product versus services organizations. Journal of Quality Management, Vol. 6, No. 1, pp. 5-27.

O'FARREL, P. (1986). The Nature of New Firms in Ireland: Empirical Evidence and Policy Implications, New Firms and Regional Development in Europe, London: Croom Helm, pp. 151-183.

Official pages iso.org. International organization for standardization, Retrieved June 1, 2010 from http://www.iso.org/iso/home.html.

Official pages John stark associates. Retrieved June 1, 2010, from http://www.johnstark.com/fwtqm.html.

Official pages mpo.cz. Finanční analýzy podnikové sféry průmyslu a stavebnictví v př́slušných letech, Retrieved June 1, 2010, from http://www.mpo.cz/cz/ministr-aministerstvo/analyticke-materialy/.

Official pages npj.cz. Informace o Národním systému kvality služeb v cestovním ruchu, Retrieved June 1, 2010, from http://www.npj.cz/soubory/dokumenty/informace-onarodnim-systemu-kvality-sluzeb-v-cr-doc1269958794.doc.

Official pages unwto.org. Improving Competitiveness, Retrieved March 31, 2010, from http://www.unwto.org/quality/index.php.

ORSER, B. J., HOGARTH-SCOTT, S., RIDING, A. L. (2000). Performance, Firm Size and Management Problem Solving, Journal of Small Business Management. Vol. 38, No. 4, pp. 42-58.

PARASURAMAN A., ZEITHAML V. A., BERRY L. L. (1988). SERVQUAL: a multiple item scale for measuring customer perceptions of service quality. Journal of Retailing. Vol. 64, No. 1, pp. 12-40. 
PARASURAMAN, A., ZEITHAML, V. (2006). Understanding and Improving Service Quality: A Literature Review and Research Agenda. In WEITZ, B., WENSLEY, R. (Ed.), Handbook of Marketing. London: Sage Publications.

PARASURAMAN, A., ZEITHAML, V. A., BERRY, L. L. (1985). A conceptual model of service quality and its implications for future research. The Journal of Marketing. Vol. 49, No. 4, pp. 41-50.

PARASURAMAN, A., ZEITHAML, V. A., BERRY, L. L. (1994). Reassessment of expectations as a comparison standard in measuring service quality: implications for further research. The Journal of Marketing. Vol. 58, No. 1, pp 111-124.

RICHARD, O. C. (2000). Racial Diversity, Business Strategy and Firm Performance: A ressource Based View. Academy of Management Journal. Vol. 43, No. 2, pp. 164-177.

ROBINSON, P. B., SEXTON, E. A. (1994). The Effect of Education and Experience of Self-Employment Succes, Journal of Business Venturing. Vol. 9, No. 2, pp. 141-156.

SANTOS-VIJANDE, M. L, ALVAREZ-GONZALES, L. I. (2007). TQM and firms performance: An EFQM excellence model research based survey. International Journal of Business Science and Applied Management. Vol. 2, No. 2.

SEXTON, E. A.; ROBINSON P. B. (1989). The Economic and Demographic Determinants of Self Employment, Frontiers of Entrepreneurship Research, Babson College, pp. 28-42.

SHEA, C., HOWELL, J. (1998). Organizational antecedents to the successful implementation of total quality management. Journal of Quality Management. Vol. 3, pp. 3-24. DOI: 10.1016/S1084-8568(99)80101-1.

SMITH, N. R., BRACKER, J. S., MINER, J. B. (1987). Correlates of Firms and Entrepreneur Succes in Technologically Innovative Companies. Frontiers of Entrepreneurship Research: Babson Collage Press, pp. 57-71.

SRINAVASAN R., WOO, C. Y., COOPER, A. C. (1994). Performance Determinants for Men and Female Entrepreneurs, Frontiers of Entrepreneurship Research, Babson College.

SUBEDI, D., MAHESHWARI, S. (2007). Impact of total quality management (TQM) on profitability and efficiency of Baldridge award winners. Delhi Business Review X, Vol. 8, No. 1.

TAKEUCHI, H., QUELCH, J. A. (1983). Quality is more than making a good product. Harvard business review. Vol. 61, pp. 139-145.

TAYLOR, S. A., BAKER, T. L. (1994). An assessment of the relationship between service quality and customer satisfaction in the formation of consumers' purchase intentions. Journal of retailing, Vol. 70, No. 2, 1994, pp. 163-178.

TAYLOR, W. A., WRIGHT, G. H. (2003). A longitudinal study of TQM implementation: factors influencing success and silure. Omega, Vol. 31, pp. 97-111.

TERZIOVSKI, M., SAMSON, D. (1999). The link between total quality management practice and organizational performance. International Journal of Quality and 
Reliability Management, Vol. 1, No. 3, pp. 226-237, DOI: 10.1108/02656719910223728.

VAJČNEROVÁ, I., RYGLOVÁ, K. (2010). Approaches to the quality management in tourism services. Acta univ. agric. et silvic. Mendel. Brun. No. 6, pp. 607-612.

WESTHEAD, P., WRIGHT, M.UCBASARAN, D. (2001). The Internationalization of New and Small Firms: A Resource-Based View, Journal of Business Venturing. Vol. 16, No. 4, pp. 333-358.

WRUCK, K. H., JENSEN, M. C. (1994). Science, Specific Knowledge and Total Quality Management. Journal of Accounting and Economic. Vol. 18, No. 3, pp. 247287.

YORK, K. M., MIREE, C. E. (2004). Causation or covariation: an empirical reexamination of the link between TQM and financial performance. Journal of Operations Management. Vol. 22, pp. 291-311. DOI: 10.1016/j.jom.2004.02.001.

ZEITHAML, V. A., PARASURAMAN, A., BERRY, L. (1990). Delivering Quality Service. New York: The Free Press. 


\title{
RELATIONSHIP BETWEEN QUALITY AND PERFORMANCE: TOURISM COMPANIES IN THE CZECH REPUBLIC
}

\section{Milan Sedláček, Petr Suchánek, Jiří Špalek, Petra Štamfestová}

Faculty of Economics and Administration, Masaryk University, Lipová 41a, 60200 Brno, Czech Republic, e-mail: milan.sedlacek@mail.muni.cz, suchycz@yahoo.com, spalek@econ.muni.cz, stamfestova.petra@mail.muni.cz

\begin{abstract}
This article analyzes perception of quality as a factor of performance of companies operating in the tourism industry. The introduction defines business performance and quality with a focus on tourism companies. A synthesis of findings from empirical studies conducted abroad follows, and is focused on the determinants of performance of a company (success), including the quality management which emerged as one of the important factors, and so these findings justify the importance of quality management in business practice. The aim of this article is to find the perception of quality and emphasis on the quality management of tourism companies in the Czech Republic. To identify the specific characteristics of quality perception and management in this sector, comparative analysis of questionnaire results, and results of a financial analysis of companies from various sectors of the Czech economy, with emphasis on tourism, has been used. It has been proved that enterprises in the sectors surveyed perceive quality as the key factor in business performance; it was also empirically shown that companies with higher levels of service quality reach better values of financial indicators. Also it was found that although tourism companies perceive the service quality of as one of the key success factors, the level of its actual implementing is low. This is related to the fact that relatively good financial results can be achieved in this industry without adjustment of the maximum customer service. This fact is also confirmed by the findings that show that in comparison to companies in other sectors, tourism companies still perceive relationship between quality production and business performance as substandard.
\end{abstract}

Key words: competitiveness, quality, financial analysis

JEL Classification: L83,L15, L25, M21

DOI: $10.2478 / \mathrm{v} 10135-011-0013-\mathrm{Z}$ 